\title{
Intratesticular Sertoli Cell Tumor: About A Case and Literature Review
}

Tarik Mhanna ${ }^{1,2 *}$, Anaour El Moudane ${ }^{1}$, Ali Barki ${ }^{1}$ and Ciprian Frasinescu ${ }^{2}$

${ }^{1}$ Department of Urology, Mohammed the first University Oujda, Morocco

${ }^{2}$ Service de Chirurgie Urologique, France

Submission: November 4, 2019; Published: November 11, 2019

*Corresponding author: Tarik Mhanna, Department of urology, Mohammed IV university medical center, bp 60050 oujda, Morocco

Abstract

Sertoli cell tumors (SCT) are very rare testicular tumors, representing $0.4 \%$ to $1.5 \%$ of all testicular malignancies. They are subclassified as classic, large-cell calcifying, and sclerosing Sertoli cell tumors. We report a case of a Sertoli cell tumor of the testis in a 37-year-old man. His chief complaint was a testicular pain right, that he had for 4 months. Serum levels of tumor markers were within normal limits. Radical orchiectomy was performed. Histopathology showed a Sertoli cell tumor with no evidence of malignancy. Through the observation and review of the literature which we will discuss the clinical and therapeutic features of this rare entity.

Keywords: Testis; Sertoli cell tumor; Orchiectomy

\section{Introduction}

Tumours of the stroma and testicular sex cords account for $3-4 \%$ of all testicular tumours. Within this group, Sertoli cell tumours make up less than $1 \%$ of testicular tumours [1]. Only $10 \%$ of these tumours are metastatic and are considered malignant. They can be found at any age, but with a spike in frequency between 30 and 40 years. They occur in $40 \%$ of cases in a dysgenetic context [2]. The most common clinical finding is a painless scrotal mass, with a third of the cases associated with gynecomastia and hormonal imbalance.

\section{Case Reports}

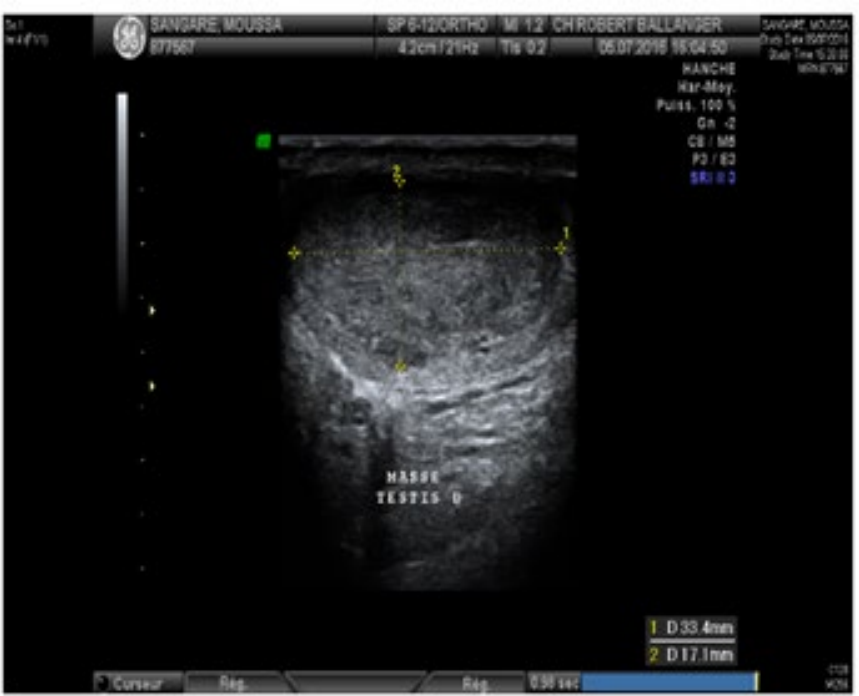

Figure 1: Ultrasound Image Showing a Voluminous Tissue Nodular Formation Measuring $27 \mathrm{Mm}$ X $16 \mathrm{Mm}$ X $30 \mathrm{Mm}$. 


\section{Global Journal of Reproductive Medicine}

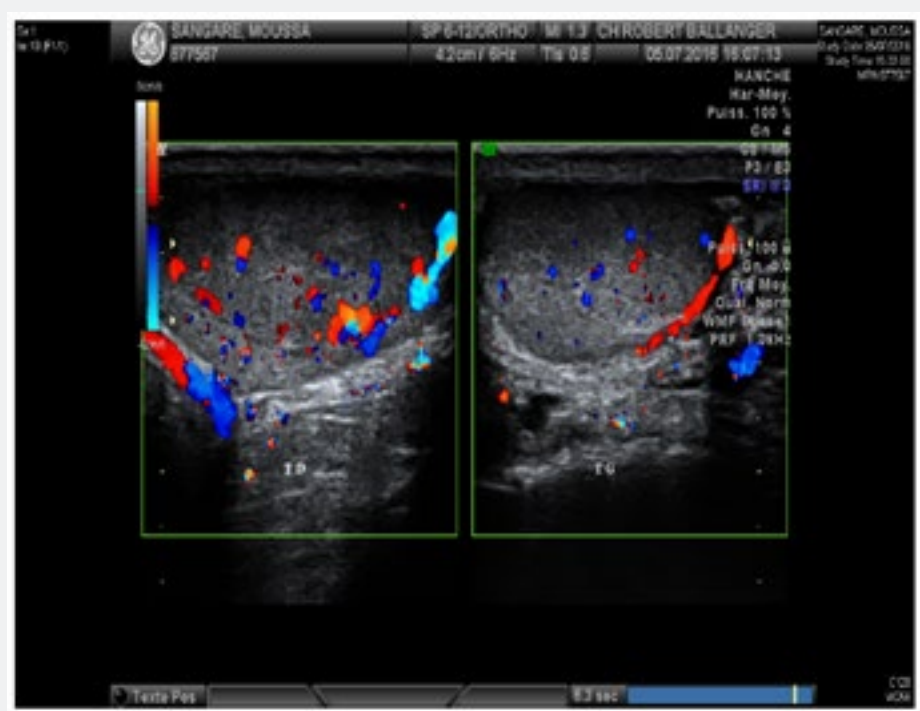

Figure 2: Color Doppler Ultrasound Image Hyper Vascularized Tissue Lesion of the Right Testis on the Periphery and in the Center.

We report the case of a 37-year-old patient, who was admitted to our structure for treatment of right testicular pain that has been evolving for 4 months. The patient's history mainly included sickle cell disease. Clinical examination revealed a left testicle of normal consistency, a straight testis increased in volume without palpable nodules but of much firmer consistency than on the left. The scrotal ultrasound revealed this right intra-testicular tissue lesion, of regular contours, occupying almost the whole of the testicular parenchyma, measuring in its large dimensions 33.4 X $17 \mathrm{~mm}$ (Figure 1), This nodule is vascularized on the periphery and in the center (Figure 2). Left testicle and epididymis of strictly normal ultrasound appearance. Tumor biomarkers ( $\alpha \mathrm{FP}, \beta \mathrm{HCG}$, and LDH) were normal. We decided to do a thoraco abdominal CT that does

not find metastasis at a distance, and two sperm samples for selfpreservation at the CECOS level. Faced with these elements a right inguinal orchidectomy after clamping first cord was performed. The postoperative course was simple.

The macroscopic anatomo-pathological examination showed a piece of orchiectomy comprising a cord and a testicle of $4.5 \times 3.5$ $\mathrm{x} 2 \mathrm{~cm}$. At the cut, the testicular parenchyma contains a yellowish solid lesion discretely lobulated without necrotic or haemorrhagic reworking. This lesion, although limited, measures $2.8 \times 2.1 \mathrm{~cm}$ and does not macroscopically infiltrate the epididymis, the tunica albuginea or the testile hilum. On microscopic examination it is a proliferation of diffuse architecture, lobulated or trabecular. This lesion consists of cubo-cylindrical cells with eosinophilic cytoplasm containing an oval nucleus, sometimes a little irregular, with a fine chromatin, without a prominent nucleolus. There are some nuclear atypias and rare mitoses. From the topographic point of view, the well-limited tumor is unencapsulated remaining of strictly intra-testicular localization. The excision limits are healthy. The immune labelings revealed reveal that the tumor cells express an intense labeling for calretinin and vimentin. Presence of a more discreet marking for Melan A. Proliferation index Ki 67: 5\%. In view of these aspects, the histological aspect and the immunohistochemical profile evoke a Sertoli cell tumor. The patient's file was discussed in the multidisciplinary oncology consultation, the decision was to perform simple monitoring.

\section{Discussion}

Gonadal stromal cells and sex cords are derived embryologically from the genital crest [3]. There are different types of Sertoli cell tumors: Variant without further indication, sclerosing, high in lipids, large calcifying cells and malignant Sertoli tumors [4]. Sertoli cell tumors usually occur in post-pubertal subjects, mean age 45 years at the time of diagnosis [4]. But can occur at any age, including neonates. Although the development of most SCT occurs at normal testicle level, there are reported cases on cryptorchidic testicles [5]. SCT is usually sporadic but can occur in a dysgenetic context such as:

a) The Carney complex, of autosomal dominant inheritance (PRKAR1 gene mutation), which variable associates cutaneous lentiginosis, myxomas, adrenocortical hyperplasia, pituitary adenoma, schwannoma.

b) Peutz-Jeghers syndrome, of autosomal dominant inheritance (LKB1 / STK11 tumor suppressor gene mutation) involving cutanomucous lentiginosis, gastrointestinal hamartomatous polyps and increased susceptibility to different tumors;

c) Androgen insensitivity syndrome [4].

The most common clinical manifestation in SCT is the slow and progressive development of painless testicular mass. About one-third of the tumors in Sertoli cells are associated with 


\section{Global Journal of Reproductive Medicine}

gynecomastia, explained by the production of estrogens by tumor cells, but it is not clear that estrogen is produced by Sertoli cells or stromal cells [6]. In children, we can also see early pseudopuberty. From the anatomopathological point of view, the SCT presents itself Macroscopically in the form of a nodular mass, uniform or multifocal with a very limited appearance, firm and solid of whitish grey colour. Microscopically: In well-differentiated tumors, SERTOLI cells are arranged in tubules separated by a fibrous stroma. The cells are arranged perpendicular to the axis of the tube. They have a cytoplasmic vacuolization realizing a micro-cystic aspect. For its less differentiated forms, histological diagnosis can be difficult. One of the main criteria for the histological diagnosis of SCT is the ability of Sertoli cells to form tubes. From a phenotypic point of view, TCS show a marking with anti-cytokeratin antibodies, vimentine, EMA (epithelial antigen membrane) and sometimes NSE (neuron specific enolase) The main histological differential diagnosis is represented by Leydig cell tumors, which also derive from sex cords and therefore have close architectural and cytological characteristics. A large tumor, irregular margins, adjacent tissue invasion, lymphatic or vascular invasion and mitotic patterns usually indicate a malignant tumor of Sertoli cells, but the presence of metastasis is essential to prove that a tumor is clinically malignant $[5,6]$.

Metastases can be late and have a morphology different from the initial tumor (better or worse differentiation than the initial tumor) making their diagnosis sometimes difficult. They are ganglionic, retroperitoneal and visceral (lung, liver, bone) [7,8]. Young et al, [5] in their 3.8-year average follow-up of 16 patients with Sertoli cell tumors after radical orchiectomy; three of 12 patients who did not have metastases initially had metastases late. Histologically, two of these three patients had microvascular invasion, two with nuclear pleomorphism and necrosis in one patient. The prognosis for a benign form of SCT is good, but the prognosis for malignant forms has not been well established. Metastatic tumors of Sertoli cells have a poor prognosis; Godec [9] reported an average survival of 15 months after Diagnosis of metastasis in nine patients. The last cases of metastases reported in the literature occurred 10 years after a radical orchidectomy [10]. Kolon et al, [11] suggested that a 5-year follow-up is necessary because of the characteristics of the tumor. In our case, we think that the prognosis of our patient will be good because of the small size of the mass, absence of histological abnormalities indicative of malignancy, and absence of evidence of metastatic localization. But close monitoring will be needed to detect late metastases. Therapeutic management Repose on orchiectomy in benign forms, an enucleation could be considered. Complete excision of the lesion is necessary to establish the diagnosis. In bilateral forms, unilateral orchiectomy with contralateral partial surgery is proposed. Retroperitoneal curettage is poorly documented in the literature. Lindegaard [12] on a series of 21 metastatic SCT reports 5 lesions. Radiation therapy has not been proven effective in SCT. Chemotherapy in metastatic SCT situations is not standardized, it relies on Cisplatin-based protocols by analogy with tumors of ovarian granulosa.

\section{Conclusion}

Stromal Sertoli cell tumors and sex cords are rare. Malignancy, although exceptional, should be considered whenever there is a large tumor (greater than $5 \mathrm{~cm}$ ) associated with cytonuclear polymorphism and significant mitotic activity. Orchiectomy is the treatment of choice.

\section{Consent of Patients}

Written informed consent was obtained from the patient's next of kin for publication of this case report and any accompanying images. A copy of the written consent is available for review by the Editor-in-Chief of this journal.

\section{References}

1. Snyder HM, D Angio GJ, Evans AE, Beverly Raney R (1992) Neoplasms of the testis. In: PC Walsh, AB Retik, TA Stamey, ED Vaughan, (Edt.), Campbell's Urology, (6 ${ }^{\text {th }}$ Edn). Edited by Philadelphia WB. Saunders Co, USA, pp. 1251-1252.

2. Kaluzny A, Matuszewski M, Wojtylak S, Krajka K, Cichy W, et al. (2012) Organsparing surgery of the bilateral testicular large cell calcifying sertoli cell tumor in patient with atypical Peutz-Jeghers syndrome. Int Urol Nephrol 44(4): 1045-1048.

3. Perito PE, Ciancio G, Civantos F, Politano Va (1992) Sertoli - Leydig cell testicular tumor: case report and review of sex gonadal stromal tumor histogenesis. J Urol 148(3): 883-885.

4. Sesterhenn IA, Jacobsen GK, Cheville J, Nistal M, Woodward PJ (2004) In: Eble JN, Sauter G, Epstein JI, Sesterhenn IA, (Edt,). World Health Organization. Classification of Tumors. Pathology and Genetics of Tumors of the Urinary System and Male Genital Organs. Lyon: IARC Press, USA, pp. 252-255.

5. Young RH, Koelliker DD, Scully RE (1998) Sertoli cell tumors of the testis, not otherwise specified: a clinicopathologic analysis of 60 cases. AM J Surg Pathol 22(6): 709-721.

6. Richie JP, Steele GS (2007) Neoplasms of the testis. In: Wein AJ, Kavoussi LR, Novick AC, Partin AW, Peters CA, (Edt)). Campbell's urology, ( $9^{\text {th }}$ edn). Saunders, Philadelphia, USA, pp. 893-935.

7. De Raeve H, Schoonooghe P, Wibowo R, Van Marck E, Goossens A (2003) Malignant large cell calcifying Sertoli cell tumor of the testis. Pathology 199: 113-117.

8. Peterson F, Bulimbasic S, Sima R, Michal M, Hora M, et al. (2010) Large cell calcifying Sertoli cell tumor: a clinicopathologic study of 1 malignant and 3 benign tumors using histomorphology, immunohistochemistry, ultrastructure, comparative genomic hybridization, and polymerase chain reaction analysis of the PRKAR1A gene. Hum Pathol 41(4): 552559.

9. Godec CJ (1985) Malignant Sertoli cell tumor of testicle. Urology 26: 185-188.

10. Comperat E, Tissier F, Vieillefond A (2004) Late metastasis after a testicular Sertoli cell tumor. Ann Pathol 24(1): 45-46.

11. Kolon TF, Hochman HI (1997) Malignant Sertoli cell tumor in a prepubescent boy. J Urol 158(2): 608-609.

12. Lindegaard-Madsen E, Morck-Hultberg B (1990) Metastatisizing Sertoli cell tumors of the human testis. A report of two cases and a review of the literature. ACTA ONCOL 29(7): 946. 
Your next submission with Juniper Publishers will reach you the below assets

- Quality Editorial service

- Swift Peer Review

- Reprints availability

- E-prints Service

- Manuscript Podcast for convenient understanding

- Global attainment for your research

- Manuscript accessibility in different formats

( Pdf, E-pub, Full Text, Audio)

- Unceasing customer service

Track the below URL for one-step submission https://juniperpublishers.com/online-submission.php 